\title{
Organic zinc supplementation in early-lactation dairy cows and its effects on zinc content and distribution in milk and cheese
}

\author{
N. N. Xu, D. T. Yang, C. Miao, T. G. Valencak, J. X. Liu, $\odot$ and D. X. Ren* $\odot$
}

\section{Graphical Abstract}

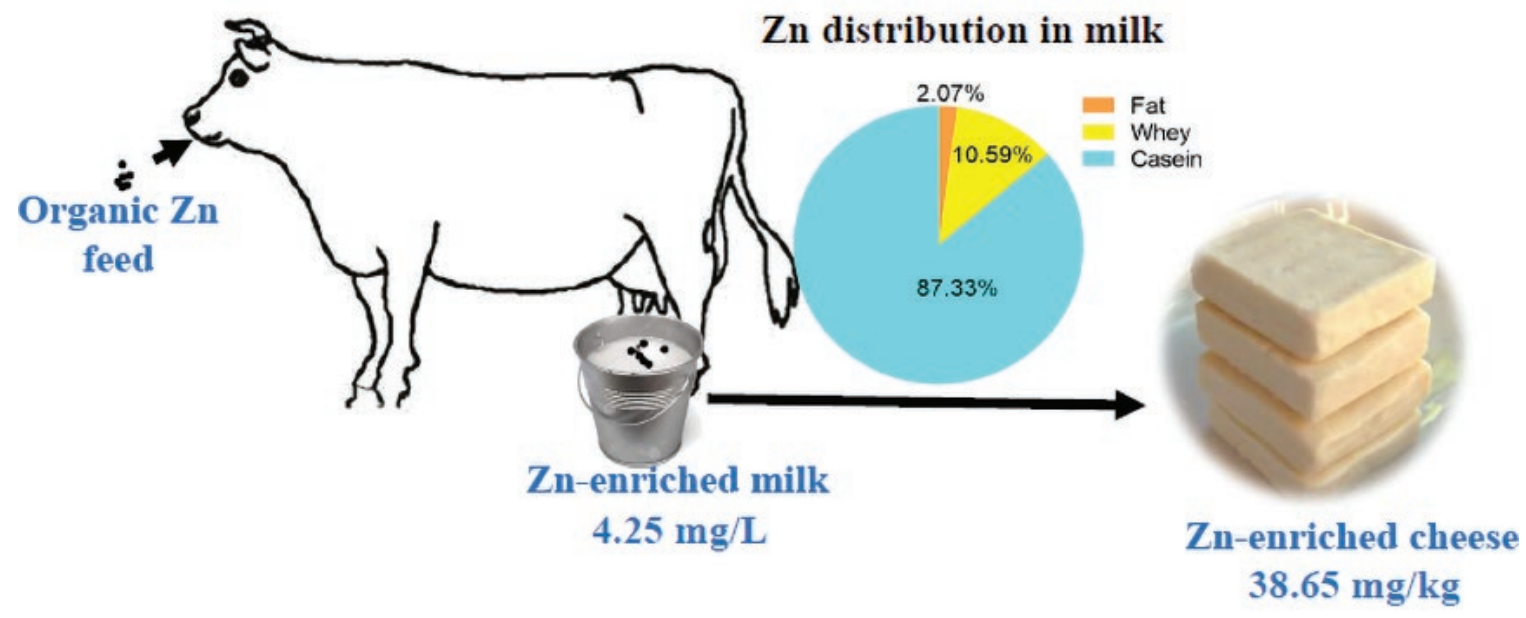

\section{Summary}

Zinc (Zn) is an important dietary ingredient for human and animal health. Our previous study found that feeding organic $Z n$ to dairy cows increased $Z n$ content in milk. In this study, supplementation of organic $Z n$ significantly increased $\mathrm{Zn}$ content in both raw milk and mozzarella cheese. Most $\mathrm{Zn}$ was retained in cheese during cheese making. The results indicate that feeding organic $\mathrm{Zn}$ is beneficial for increasing $\mathrm{Zn}$ content in milk and cheese and that most $Z n$ remained in cheese during cheese making and subsequent ripening processes.

\section{Highlights}

- Organic Zn supplementation improves fat content in raw milk.

- Organic Zn supplementation in feed improves zinc content in cheese.

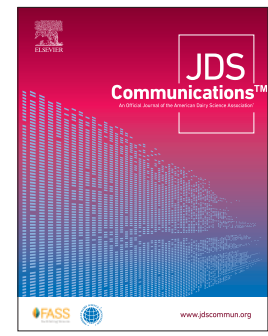

- Zinc mostly distributed in casein.

- Zinc is stable during cheese making and storage. 


\title{
Organic zinc supplementation in early-lactation dairy cows and its effects on zinc content and distribution in milk and cheese
}

\author{
N. N. Xu, D. T. Yang, C. Miao, T. G. Valencak, J. X. Liu, $\odot$ and D. X. Ren* ${ }^{*}$
}

Abstract: This study investigated the effects of organic zinc ( $\mathrm{Zn}$ ) supplementation in early-lactation dairy cows on $\mathrm{Zn}$ content and distribution in raw milk and mozzarella cheese. Thirty-four multiparous dairy cows in early lactation were randomly assigned to 2 groups: basal diet (control; CON) and basal diet supplemented with a Zn AA complex (CZ). After feeding the diets for 8 wk, raw milk was collected for manufacturing mozzarella cheese. Total $\mathrm{Zn}$ content and $\mathrm{Zn}$ distribution in raw milk and cheese were determined by atomic absorption spectrophotometry. Results showed that milk fat content was significantly increased in the CZ group compared with the CON group. No significant differences in fat, protein, and moisture contents of cheese were observed between the 2 groups. Zinc contents in milk (4.25 vs. $3.85 \mathrm{mg} / \mathrm{L})$ and cheese (38.65 vs. $27.20 \mathrm{mg} / \mathrm{kg})$ were significantly higher in the CZ group than in the CON group. Little Zn was lost in stretch water $(<0.04 \mathrm{mg} / \mathrm{L})$ and brine $(<0.01 \mathrm{mg} / \mathrm{L})$ during the cheese-making process. Most of the $\mathrm{Zn}$ was detected in casein $(87.3 \%$ vs. $88.4 \%)$ of the raw milk, and then in the whey $(10.6 \%$ vs. $9.88 \%)$ and fat $(2.07 \%$ vs. $1.77 \%)$. Organic Zn supplementation in early-lactation cows increased $\mathrm{Zn}$ content in raw milk and mozzarella cheese, and $\mathrm{Zn}$ remained stable during cheese making.

Z inc $(\mathrm{Zn})$ is an essential mineral for the catalytic activities of more than 100 enzymes and plays an important role in immune function, protein synthesis, and cell division. The primary cause of $\mathrm{Zn}$ deficiency is low dietary intake combined with limited capacity to store $\mathrm{Zn}$ in the body. Thus, continuous dietary intake of $\mathrm{Zn}$ is necessary for normal health and maintenance. However, approximately 2 billion people around the world have insufficient daily Zn intake (Song et al., 2010). Globally, almost 16 million people may suffer from Zn deficiency (Brown et al., 2004). Insufficient $\mathrm{Zn}$ intake restricts prepubertal physical growth of children and increases their risk of infection. Maintaining an adequate dietary $\mathrm{Zn}$ intake is an efficient way to combat $\mathrm{Zn}$ deficiency, especially among children and older adults. Recommended dietary allowances of $\mathrm{Zn}$ in the United States are 11 and $8 \mathrm{mg} / \mathrm{d}$ for men and women, respectively (Food and Nutrition Board and Institute of Medicine, 2001), and requirements are even higher for pregnant and nursing women.

Low dietary intake of absorbable $\mathrm{Zn}$ is the primary cause of $\mathrm{Zn}$ deficiency. In a study by Talsma et al. (2017), consuming a combination of milk and phytate-rich rice increased the total amount of absorbable $\mathrm{Zn}$ from rice, suggesting that $\mathrm{Zn}$-rich dairy products can potentially increase dietary absorbable $\mathrm{Zn}$ concentration. Ianni et al. (2019) found that feeding dairy animals with Zn was a promising method to increase $\mathrm{Zn}$ content in dairy products. Studies have also found that $\mathrm{Zn}$ supplementation increases $\mathrm{Zn}$ content in milk (Martino et al., 2019) and that nutrition components and aromatic compound profiles of cheese can be enhanced by feeding dairy animals with Zn additives (Ianni et al., 2019; Martino et al., 2019).

Our previous study found that feeding a Zn AA complex supplement significantly improved milk protein and fat contents (C. Miao, unpublished data). Today's consumers expect high quality and health benefits from their foods (Annunziata and Mariani, 2018). Thus, high-quality cheese production should include Zn-enriched dairy products. However, the effects of feed $\mathrm{Zn}$ supplementation on $\mathrm{Zn}$ content and distribution in milk and cheese remain unclear. The aim of our study was to investigate the effects of feed $\mathrm{Zn}$ supplementation on Zn content and distribution in milk and mozzarella cheese as well as $\mathrm{Zn}$ stability during cheese storage.

Our current study was conducted at Zheng-Xing Dairy Farm, Hangzhou, China. Thirty-four healthy multiparous dairy cows in early lactation were randomly allocated into 2 groups: basal diet (control; CON) and basal diet supplemented with $10.4 \mathrm{~g}$ of a $\mathrm{Zn}$ AA complex (Zinpro-Zn170, Zinpro Animal Nutrition Inc.) per day per cow according to the recommended dosage $(\mathbf{C Z})$. Zinc content in the CON and CZ groups was 60 and $140 \mathrm{mg} / \mathrm{kg}$, respectively. The Zn AA complex product was chelated by Zn-lysine and $\mathrm{Zn}$-glutamic acid 1:1 with $170 \mathrm{~g} / \mathrm{kg} \mathrm{Zn}$ in the premix. The composition and chemical profiles of the basal diet are shown in Table 1. Raw milk samples from the 2 groups were collected after 8 wk of supplemented feeding, and milk compositions were analyzed by infrared spectroscopy using a MilkoScan FT 120 (Foss Electric). Milk samples were stored at $-20^{\circ} \mathrm{C}$ until subsequent $\mathrm{Zn}$ analyses.

Thirty liters of raw milk was collected from both the CON and $\mathrm{CZ}$ groups at the same time and was standardized through partial skimming based on a protein:fat ratio of 3.3:3.5. Subsequently, the raw milks were pasteurized at $63^{\circ} \mathrm{C}$ for $30 \mathrm{~min}$, followed by cooling to $35^{\circ} \mathrm{C}$. Mozzarella cheese was manufactured according to the modified method as described previously (Liu et al., 2018). Cheese samples were collected after 1, 4, and $8 \mathrm{wk}$ of storage. The whey, stretching water, and brine produced during cheese making were also collected and stored at $-20^{\circ} \mathrm{C}$ until $\mathrm{Zn}$ content was determined. Raw milk was collected 3 times during the 9 wk, 
Table 1. Ingredients and composition (\% of DM unless otherwise noted) of the basal diet used in this study

\begin{tabular}{lc}
\hline Item & Value \\
\hline Ingredient & \\
Spanish alfalfa & 4.6 \\
American alfalfa & 8.2 \\
Chinese oat grass & 4.5 \\
Imported oatmeal & 3.4 \\
Corn silage & 21.0 \\
Cottonseed & 5.8 \\
Beet pulp & 7.0 \\
Brewers spent grains & 11.5 \\
Concentrate & 33.0 \\
Total & 100.0 \\
Chemical profile & \\
CP & 17.0 \\
NDF & 30.2 \\
ADF & 18.3 \\
Ash & 7.37 \\
Ether extract & 5.1 \\
Zn, mg/kg & 70.5 \\
\hline
\end{tabular}

and mozzarella cheese was made upon collection. Composition of cheese samples was measured in triplicate for each batch.

The moisture, fat, and protein contents of cheese from both groups were determined with the oven-drying method (IDF, 1958), Gerber method (NSAI, 1955), and micro-Kjeldahl method (IDF, 1993), respectively. Then, the moisture content in nonfat substances and fat content in DM were calculated based on the results from basic fat and moisture contents.

The $\mathrm{Zn}$ content in raw milk, cheese, and by-products was analyzed according to the China national food safety standard GB 5009.14-2017 (NHFPC, 2017). Briefly, cheese (2.51 $\pm 0.14 \mathrm{~g})$, whey $(3.15 \pm 0.06 \mathrm{~mL})$, raw milk $(4.19 \pm 0.03 \mathrm{~mL})$, stretch water $(4.21 \pm 0.05 \mathrm{~mL})$, and brine $(4.18 \pm 0.04 \mathrm{~mL})$ were initially treated with $10 \mathrm{~mL}$ of nitric acid and $0.5 \mathrm{~mL}$ of perchloric acid overnight and further digested using a microwave oven according to a digestion protocol $\left(120^{\circ} \mathrm{C}\right.$ for $60 \mathrm{~min}, 180^{\circ} \mathrm{C}$ for $120 \mathrm{~min}$, and held at 200-220 ${ }^{\circ} \mathrm{C}$ ). Then, the ash was dissolved with $25 \mathrm{~mL}$ of deionized water. The Zn content of milk, cheese, and by-products was determined using atomic absorption spectrophotometry (Unicam Solaar 989, Thermo Elemental Corp.) at $213.9 \mathrm{~nm}$. Zinc analysis standard curves at $0,0.10,0.20,0.40,0.80$, and $1.00 \mathrm{mg} / \mathrm{L} \mathrm{Zn}$ concentrations were prepared in $100-\mathrm{mL}$ volumetric flasks with nitric acid (5\%) matrix modifier from a $10.0 \mathrm{mg} / \mathrm{kg} \mathrm{Zn}$ solution. The final $\mathrm{Zn}$ content was calculated according to the standard curve.

The Mixed procedure of SAS 9.4 (SAS Institute Inc.) was applied to analyze the $\mathrm{Zn}$ content of cheese and milk. The model used was

$$
Y_{i j}=\mu+T_{i}+e_{i}
$$

where $Y_{i j}$ was the observation of dependent variable $i$; $\mu$ was the population mean; $T_{i}$ was the effect of Zn AA complex supplementation on cheese composition and $\mathrm{Zn}$ content; and $e_{i}$ was the random error. Significance was set at $P \leq 0.05$.

Raw milk composition is shown in Table 2. Dietary Zn supplementation significantly increased milk fat content $(3.52 \mathrm{vs} .3 .99 \mathrm{~g} /$ $\mathrm{kg} ; P<0.05)$. No effect was observed on milk protein content $(3.32$ vs. $3.38 \mathrm{~g} / \mathrm{kg}$ ), resulting in a lower protein:fat ratio in the $\mathrm{CZ}$ group
Table 2. Composition of raw milk and cheese (means \pm SD) from the 2 experimental groups ${ }^{1}$

\begin{tabular}{lcc}
\hline Item & CON & $C Z$ \\
\hline Raw milk & & \\
Protein, g/kg & $3.32 \pm 0.01$ & $3.38 \pm 0.01$ \\
Fat, g/kg & $3.52 \pm 0.02^{\mathrm{b}}$ & $3.99 \pm 0.01^{\mathrm{a}}$ \\
Protein/fat & $0.94 \pm 0.00^{\mathrm{a}}$ & $0.84 \pm 0.01^{\mathrm{b}}$ \\
Cheese, $\%$ & & \\
Fat & $21.34 \pm 1.65$ & $22.02 \pm 0.5$ \\
Protein & $19.64 \pm 0.65$ & $20.11 \pm 0.15$ \\
Moisture & $52.96 \pm 1.51$ & $50.50 \pm 0.62$ \\
Fat in DM & $45.37 \pm 3.16$ & $44.48 \pm 1.10$ \\
MNFS $^{2}$ & $67.32 \pm 1.79$ & $66.76 \pm 0.86$ \\
\hline
\end{tabular}

${ }^{a, b}$ Means within a row with different superscripts were significantly different $(P<0.05)$

${ }^{1} \mathrm{CON}=$ basal diet (control; $\mathrm{n}=3$ ); $\mathrm{CZ}=$ basal diet supplemented with $10.4 \mathrm{~g}$ of a Zn AA complex (Zinpro-Zn170, Zinpro Animal Nutrition Inc.) per day per cow according to the recommended dosage $(n=3)$.

${ }^{2}$ Moisture in nonfat substances.

(0.94 vs. $0.84 ; P<0.05$ ). Nayeri et al. (2014) found that dietary supplementation with a mixture of $\mathrm{Zn}$ sulfate and $\mathrm{Zn}$ AA complex was beneficial for lactation performance and milk composition. However, other studies found that dietary $\mathrm{Zn}$ supplementation had no effect on raw milk and cheese composition (Cope et al., 2009; Ianni et al., 2019). Milk content was not sensitive to $\mathrm{Zn}$ supplementation based on $\mathrm{ZnO}$ and $\mathrm{Zn}$ sulfate (Cope et al., 2009; Wang et al., 2013). Similarly, our current study did not reveal a significant improvement in milk yield in the $\mathrm{CZ}$ group (data not shown). The mechanism remains unclear. We hypothesize that both the biochemical nature and the dosage of $\mathrm{Zn}$ might play key roles in improving milk yield and composition.

The composition of cheese is shown in Table 2. No differences in fat, protein, and moisture contents, fat content in DM, and moisture content in nonfat substances were observed between $\mathrm{CON}$ and $\mathrm{CZ}$ cheeses, probably because the milk had to undergo a standardization process before manufacturing cheese. Ianni et al. (2019) also found that $\mathrm{Zn}$ supplementation in Friesian cows did not affect fat and protein contents in fresh and ripened cheese. Martino et al. (2019) found that the composition of fresh and ripened cheese did not differ between the control and the $\mathrm{Zn}$-supplemented group. Results of our study indicate that dietary $\mathrm{Zn}$ supplementation as in the $\mathrm{CZ}$ group did not affect any of the cheese micronutrients and moisture content.

The $\mathrm{Zn}$ content of milk is shown in Table 3. The highest recommended dietary $\mathrm{Zn}$ content for dairy cows is $73 \mathrm{mg} / \mathrm{kg}$ of DM over the whole life cycle (NRC, 2001), indicating that the supplemented $\mathrm{Zn}$ content in our current study was sufficient. The $\mathrm{Zn}$ content of CON milk was comparable with that of raw milk in a study reported by Raynal-Ljutovac et al. (2008). The additional dietary $\mathrm{Zn}$ supplementation increased the $\mathrm{Zn}$ content (3.85 vs. $4.25 \mathrm{mg} / \mathrm{L}$ ) of milk $(P<0.05)$ as expected. Similarly, Martino et al. (2019) found that a $\mathrm{Zn}$-enriched diet significantly increased $\mathrm{Zn}$ content of milk. However, no effect was reported on cheese samples. As for $\mathrm{Zn}$ distribution in milk, no differences in whey, casein, and fat were observed between the 2 groups (Table 3 ). Hence, organic dietary $\mathrm{Zn}$ supplementation did not affect $\mathrm{Zn}$ distribution in milk. The $\mathrm{Zn}$ import and export metabolic process is strictly regulated by the mammary gland to maintain sufficient $\mathrm{Zn}$ supply to the neo- 
Table 3. Zinc concentration (means \pm SD) and distribution in different components of raw milk and cheese ${ }^{1}$

\begin{tabular}{lcc}
\hline Item & CON & $C Z$ \\
\hline Zinc in raw milk & & \\
$\quad$ Total, $\mathrm{mg} / \mathrm{L}$ & $3.85 \pm 0.07^{\mathrm{b}}$ & $4.25 \pm 0.07^{\mathrm{a}}$ \\
Casein, \% & $88.35 \pm 1.24$ & $87.33 \pm 2.08$ \\
Whey, \% & $9.88 \pm 0.78$ & $10.59 \pm 1.06$ \\
Fat, \% & $1.77 \pm 0.18$ & $2.07 \pm 0.13$ \\
Zinc in cheese & & \\
Total, $\mathrm{mg} / \mathrm{kg}$ & $27.20 \pm 1.56^{\mathrm{b}}$ & $38.65 \pm 3.18^{\mathrm{a}}$ \\
Whey, $\mathrm{mg} / \mathrm{kg}$ & $0.18 \pm 0.03$ & $0.27 \pm 0.09$ \\
Stretch water, $\mathrm{mg} / \mathrm{L}$ & $<0.02$ & $<0.04$ \\
Brine, $\mathrm{mg} / \mathrm{L}$ & $\mathrm{ND}^{2}$ & $\mathrm{ND}$
\end{tabular}

${ }^{a, b}$ Means within a row with different superscripts were significantly different $(P<0.05)$.

${ }^{1} \mathrm{CON}=$ basal diet (control; $\mathrm{n}=3$ ); $\mathrm{CZ}=$ basal diet supplemented with $10.4 \mathrm{~g}$ of a Zn AA complex (Zinpro-Zn170, Zinpro Animal Nutrition Inc.) per day per cow according to the recommended dosage $(n=3)$.

${ }^{2}$ Not detected.

nate calf (Kelleher and Lönnerdal, 2005). This mechanism could explain the slight improvement in $\mathrm{Zn}$ concentration following supplementation.

Most $\mathrm{Zn}$ in milk is bound to the casein protein, and thus $\mathrm{Zn}$ enrichment is expected during the cheese-making process. In mozzarella cheese, the $\mathrm{Zn}$ content at normal $\mathrm{Zn}$ supply is $31 \mathrm{mg} /$ $\mathrm{kg}$ (USDA, 2010). Dietary Zn supplementation significantly ( $P$ $<0.05)$ increased the $\mathrm{Zn}$ content of cheese $(27.20$ vs. $38.65 ; P$ $<0.05)$. A higher $\mathrm{Zn}$ concentration in whey was observed in the $\mathrm{CZ}$ group (0.18 vs. 0.27 ), which probably was due to the higher $\mathrm{Zn}$ distribution in milk whey (Table 3). Little $\mathrm{Zn}$ was observed in stretch water $(<0.04 \mathrm{mg} / \mathrm{L})$ and brine $(<0.01 \mathrm{mg} / \mathrm{L})$ in both cheeses, indicating that $\mathrm{Zn}$ was not water soluble during cheese making. Because $85 \%$ of the $\mathrm{Zn}$ in milk was detected in casein micelles (Table 3), more than $95 \%$ of $\mathrm{Zn}$ in milk was maintained in the cheeses of both groups during the 8-wk storage period. Another study by Singh et al. (1989) showed that almost 100\% of Zn was retained in cheese. Furthermore, $\mathrm{Zn}$ remained stable during cheese storage for $2 \mathrm{mo}$, as almost all $\mathrm{Zn}$ was retained (98\%). Thus, dietary $\mathrm{Zn}$ supplementation provides a potential way to produce Zn-enriched milk. Similarly, Zn enrichment may have beneficial effects on human health through improved dairy products such as mozzarella cheese.

Sufficient daily $\mathrm{Zn}$ intake is essential for human health. To maintain physiological levels despite deficient $\mathrm{Zn}$ storage capabilities, increased $\mathrm{Zn}$ concentrations in raw milk may provide a suitable source of $\mathrm{Zn}$ for humans, especially those who do not consume enough meat. Coudray (2011) found that milk products represent a key source of dietary $\mathrm{Zn}$ in children. It was also reported that a significant association existed between intake of dairy products and serum Zn levels in children (Schlegel-Zawadzka et al., 2002). The increased intake of $\mathrm{Zn}$ from dairy products can further be improved by $\mathrm{Zn}$ absorption from rice, resulting in higher net daily $\mathrm{Zn}$ consumption. Thus, the significantly higher $\mathrm{Zn}$ concentration in milk and cheese indicated that dietary $\mathrm{Zn}$ supplementation in early lactation provides a useful method for $\mathrm{Zn}$ enrichment of dairy products. This may serve body health, and the consumption of $\mathrm{Zn}$ enriched cheese may become a convenient and efficient way to combat potential $\mathrm{Zn}$ deficiency.
In conclusion, dietary supplementation of organic $\mathrm{Zn}$ at $80 \mathrm{mg}$ / $\mathrm{kg}$ improved milk fat content. No difference in mozzarella cheese protein and fat contents was observed between the $\mathrm{CON}$ and $\mathrm{CZ}$ groups. Zinc content in raw milk was significantly improved by dietary $\mathrm{Zn}$ supplementation, and almost $90 \%$ of $\mathrm{Zn}$ was distributed in casein. The remaining $\mathrm{Zn}$ was found in cheese during cheese making, and $\mathrm{Zn}$ remained stable during storage. Our study indicates that dietary $\mathrm{Zn}$ supplementation improves the $\mathrm{Zn}$ content in both raw milk and cheese. These findings may be useful for the development of functional, nutritious dairy products.

\section{References}

Annunziata, A., and A. Mariani. 2018. Consumer perception of sustainability attributes in organic and local food. Recent Pat. Food Nutr. Agric. 9:87-96. https://doi.org/10.2174/2212798410666171215112058.

Brown, K. H., J. A. Rivera, Z. Bhutta, R. S. Gibson, J. C. King, B. Lönnerdal, M. T. Ruel, B. Sandtröm, E. Wasantwisut, and C. Hotz. 2004. Assessment of the risk of zinc deficiency in populations and options for its control. Food Nutr. Bull. 25:S99-S203.

Cope, C. M., A. Mackenzie, D. Wilde, and L. A. Sinclair. 2009. Effects of level and form of dietary zinc on dairy cow performance and health. J. Dairy Sci. 92:2128-2135. https://doi.org/10.3168/jds.2008-1232.

Coudray, B. 2011. The contribution of dairy products to micronutrient intakes in France. J. Am. Coll. Nutr. 30(Suppl. 5):410S-414S. https://doi.org/10 .1080/07315724.2011.10719984.

Food and Nutrition Board and Institute of Medicine. 2001. Dietary reference intakes for vitamin A, vitamin $\mathrm{K}$, boron, chromium, copper, iodine, iron, manganese, molybdenum, nickel, silicon, vanadium and zinc. Pages 442-501 in Standing Committee on the Scientific Evaluation of Dietary Reference Intakes. National Academies Press.

Ianni, A., M. Iannaccone, C. Martino, D. Innosa, L. Grotta, F. Bennato, and G. Martino. 2019. Zinc supplementation of dairy cows: Effects on chemical composition, nutritional quality and volatile profile of Giuncata cheese. Int. Dairy J. 94:65-71. https://doi.org/10.1016/j.idairyj.2019.02.014.

IDF (International Dairy Federation). 1958. Determination of dry matter in cheese and processed cheese. Standard FIL-IDF 4. International Dairy Federation.

IDF (International Dairy Federation). 1993. Milk: Determination of nitrogen content, part 3: Block digestion method (semi-micro rapid routine method), annex-modified procedure for milk products. Standard FIL-IDF 20B. International Dairy Federation.

Kelleher, S. L., and B. Lönnerdal. 2005. Molecular regulation of milk trace mineral homeostasis. Mol. Aspects Med. 26:328-339. https://doi.org/10 .1016/j.mam.2005.07.005.

Liu, C. X., C. Wang, J. X. Liu, and D. Ren. 2018. Effect of feed lutein supplementation on mozzarella cheese quality and lutein stability. Int. Dairy J. 83:28-33. https://doi.org/10.1016/j.idairyj.2018.03.008.

Martino, C., A. Ianni, L. Grotta, F. Pomilio, and G. Martino. 2019. Influence of zinc feeding on nutritional quality, oxidative stability and volatile profile of fresh and ripened ewes' milk cheese. Foods 8:656. https://doi.org/10 .3390/foods 8120656 .

National Research Council. 2001. Nutrient Requirements of Dairy Cattle. 7th rev. ed. Natl. Acad. Press.

Nayeri, A., N. Upah, E. Sucu, M. Sanz-Fernandez, J. DeFrain, P. Gorden, and L. H. Baumgard. 2014. Effect of the ratio of zinc amino acid complex to zinc sulfate on the performance of Holstein cows. J. Dairy Sci. 97:4392-4404. https://doi.org/10.3168/jds.2013-7541.

NHFPC (National Health and Family Planning Committee of China). 2017. National food safety standard $\mathrm{Zn}$ content examination in food. Accessed October 2017. https://sppt.cfsa.net.cn:8086/staticPages/145049F9-E622 -4443-A0DC-5ABE7DE5E6B7.html.

NSAI (National Standards Authority of Ireland). 1955. Determination of Percentage of Fat in Cheese (IS69). National Standards Authority of Ireland.

Raynal-Ljutovac, K., G. Lagriffoul, P. Paccard, I. Guillet, and Y. Chilliard. 2008. Composition of goat and sheep milk products: An update. Small Rumin. Res. 79:57-72. https://doi.org/10.1016/j.smallrumres.2008.07.009.

Schlegel-Zawadzka, M., Z. Zachwieja, A. Huzior-Baajewicz, and J. J. Pietrzyk. 2002. Comparative analysis of zinc status, food products' frequency intake 
and food habits of 11-year-old healthy children. Food Addit. Contam. 19:963-968. https://doi.org/10.1080/02652030210146472.

Singh, H., A. Flynn, and P. F. Fox. 1989. Binding of zinc to bovine and human milk proteins. J. Dairy Res. 56:235-248. https://doi.org/10.1017/ S0022029900026455.

Song, Y., V. Elias, A. Loban, A. G. Scrimgeour, and E. Ho. 2010. Marginal zinc deficiency increases oxidative DNA damage in the prostate after chronic exercise. Free Radic. Biol. Med. 48:82-88. https://doi.org/10.1016/j freeradbiomed.2009.10.030.

Talsma, E. F., D. Moretti, S. C. Ly, R. Dekkers, E. G. Van den Heuvel, A. Fitri, E. Boelsma, T. J. Stomph, C. Zeder, and A. Melse-Boonstra. 2017. Zinc absorption from milk is affected by dilution but not by thermal processing, and milk enhances absorption of zinc from high-phytate rice in young Dutch women. J. Nutr. 147:1086-1093. https://doi.org/10.3945/jn.116 .244426

USDA. 2010. Content of selected foods per common measure, zinc. National Nutrient Database for Standard Reference, Release 23. US Department of Agriculture.
Wang, R. L., J. G. Liang, L. Lu, L. Y. Zhang, S. F. Li, and X. G. Luo. 2013. Effect of zinc source on performance, zinc status, immune response, and rumen fermentation of lactating cows. Biol. Trace Elem. Res. 152:16-24. https://doi.org/10.1007/s12011-012-9585-4.

\section{Notes}

J. X. Liu (๑) https://orcid.org/0000-0002-5812-5186

D. X. Ren $\odot$ https://orcid.org/0000-0002-8016-0033

The current study was funded by the China Agriculture Research System (No. CARS-36) and the National Natural Science Foundation of China (No. 31872380).

The authors are grateful to the staff of the Zheng-Xing Dairy Farm (Hangzhou, China) for their assistance in milking and caring for the animals.

The authors declare they have no conflicts of interest. 